\title{
MENGEMBANGKAN KEMANDIRIAN DAN MOTORIK HALUS PADA SISWA DOWN SYNDROME DI SEKOLAH LUAR BIASA (SLB)
}

\author{
Lilik Fadlilatin Azizah, Mas'odi \\ STKIP PGRI Sumenep \\ titinazizah88@gmail.com, masodi@stkippgrisumenep.ac.id
}

\begin{abstract}
Abstrak
Down Syndrome merupakan kondisi keterbelakangan perkembangan fisik dan mental pada anak yang disebabkan adanya abnormalitas perkembangan kromosom. Diusianya yang sudah memasuki masa remaja ini, ibu Subjek selalu melayani dalam semua aktivitas harian Subjek, dalam berpakaian Subjek juga masih dibantu oleh ibunya. Setelah diberikan penanganan pada subjek, maka didapatkan hasil yang memuaskan. Kemandirian pada Subjek sudah mulai berkembang, subjek di rumah sudah tak mau dimandikan lagi, saat tiba waktu mandi subjek akan meminta peralatan mandi dan kemudian mandi sendiri, dan setelah mandi, subjek akan menggunakan pakaiannya sendiri, namun pakaian masih perlu disiapkan sebelumnya. Penelitian ini merupakan penelitian kualitatif yaitu studi kasus. Data penelitian ini berupa hasil wawancara, observasi dan sumber tertulis. Pengumpulan data dilakukan dengan menggunakan teknik wawancara dan observasi. Kegiatan analisis data dilakukan dengan cara analisis teori terhadap kasus.
\end{abstract}

Kata Kunci: Down Syndrome, Kemandirian dan Motorik Halus

\begin{abstract}
Down Syndrome is a condition of underdevelopment of physical and mental development in children caused by chromosomal development abnormalities. At her age which have entered adolescence her mother always serve Subjects in all daily activities. Subjects, in dressing Subject was also still assisted by his mother. After given the handling on the subject, then got satisfactory results. Independence on the subject has begun to develop, the subject at home was not willing to be bathed again, when the bath time the subject will ask for toiletries and then bathed himself, and after bathing, the subject will use his own clothes, but the clothes still need to be prepared before. This research uses research with qualitative of case study. This research data form of interview result, observation result and written sources. The data were collected using interview and observation techniques. The data analysis activity is done by thematic analysis.
\end{abstract}

Keywords: Down Syndrome, Independence and Smooth Motoric.

\section{Pendahuluan}

Anak adalah Anugerah terbesar yang diberikan Tuhan kepada kita umat manusia. Pada dasarnya setiap keluarga ingin mempunyai keturunan yang lahir dan tumbuh normal, tetapi kenyataannya setiap manusia yang dilahirkan di dunia ini tidak semuanya lahir dengan normal. Sebagaimana anak manusia, bagaimanapun wujud terlahir, mereka berhak mendapatkan pendidikan yang layak dan mendapatkan kesempatan yang sama untuk menikmati dunianya yaitu belajar dan bermain seperti anak-anak yang lainnya. Di balik semua itu tentu Tuhan mempunyai rahasia tersendiri sehingga ada anak yang terlahir dengan Down Syndrome.

Down syndrome adalah suatu cacat fisik bawaan yang disertai dengan keterbelakangan mental anak sejak lahir yang disebabkan abnormalitas perkembangan kromosomnya, namun kondisi satu anak Down syndrome dengan kondisi anak Down syndrome yang lainnya tentu saja berbeda (Wiyani : 114) dalam 
Lili Fadlilatin Azizah, Mas'odi

(Rohmadheni, 2016). Berdasarkan penelitian yang dilakukan oleh Lejuene (1959 dalam Gruenberg, 1966), seorang ahli genetik Prancis, penderita down syndrome memiliki 47 kromosom, sementara itu orang normal memiliki 46 kromosom. Juga diketahui adanya persentase yang tinggi tentang anak yang menderita down syndrome yang dilahirkan oleh ibu yang berusia diatas 40 tahun (Rina, 2016).

Seperti yang telah dipaparkan di atas bahwa perkembangan anak bersifat diskriptif sesuai dengan golongan umurnya, namun ada kondisi dimana anak memerlukan perhatian khusus. Seperti halnya dengan LN, siswa sekolah dasar yang semestinya sudah memasuki fase pubertas, namun hal itu tidak terjadi padanya karena keterbatasan fisik yang dimilikinya. LN sangat membutuhkan bimbingan dan penanganan yang optimal guna mengembangkan aspek kemandiriannya. Beberapa fase perkembangan yang semestinya dialami oleh anak seusianya tidak terjadi pada LN. Dari bentuk fisiknya, LN masih terlihat seperti anak yang berusia 7 tahun. LN masih belum mengalami fase-fase perkembangan seperti remaja pada umumnya, tanda-tanda perubahan fisik juga masih belum nampak. Begitu juga dengan perkembangan emosi dan penyesuaian sosialnya, LN masih belum bisa melakukan perawatan diri secara optimal. Diusianya yang sudah memasuki masa remaja ini, LN masih saja dimandikan oleh ibunya, LN masih belum mampu untuk mandi sendiri. Ibu LN selalu melayani LN dalam semua aktivitas harian LN, dalam berpakaian LN juga masih dibantu oleh ibunya, karena LN belum mampu melakukan hal tersebut. Beberapa kali LN pernah didapati memakai baju sendiri, namun hal itu tidak membuat ibunya puas, LN tidak memakai baju dengan rapih dan benar, beberapa letak kancingpun sering kali tidak teratur, oleh kerena itu ibunya tidak pernah lagi meminta LN untuk memakai bajunya sendiri. Ketika akan berangkat ke sekolah keperluan LN akan disiapkan oleh ibunya, termasuk memakaikan seragam sekolah.

Dari beberapa pengamatan yang dilakukan oleh peneliti, peneliti menemukan beberapa kejanggalan pada $L N$, diantaranya adalah aspek kemandirian $L N$ yang masih belum muncul diusianya yang bukan merupakan anak-anak lagi. LN memerlukan penanganan dan bimbingan yang dapat memacunya untuk memunculkan sikap "self helf", sehingga dengan demikian diharapkan LN mampu untuk mandiri, minimal mandiri dalam melakukan aktivitas hariannya dalam perawatan diri seperti mandi, memakai baju dan menjaga kebersihan diri. Untuk makan sendiri, LN sudah mampu melakukan sendiri tanpa bantuan dari orangtuanya, hal ini dikarenakan LN sudah mendapatkan pembiasaan ini disekolah. Kejanggalan lain yang ditemukan oleh peneliti adalah aspek motorik halus yang belum optimal dalam perkembangannya, hal ini dibuktikan dengan kesulitannya dalam memakai baju. Dalam memakai baju ada aspek motorik halus yang harus terlatih, yaitu pada saat pemasangan kancing baju, ketika hal ini tidak dapat dilakukan maka aspek motorik halus belum mampu dicapai secara optimal.

Persoalan selanjutnya yang ditemukan oleh peneliti adalah kesulitan LN dalam berkomunikasi. LN termasuk anak yang susah mengungkapkan isi hatinya melalui percakapan dengan orang-orang sekitarnya, LN terlihat susah berkata-kata. Kondisi emosinyapun susah untuk dikenali karena kesulitannya dalam berkomunikasi. LN tiba-tiba terlihat marah atau menangis tanpa sebab, namun orang-orang disekitarnya tidak memahami hal ini. 


\section{Perkembangan Remaja}

Remaja di definisikan sebagai masa peralihan dari masa kanak-kanak ke masa dewasa, batasan usia remaja berbeda-beda sesuai dengan sosial budaya setempat. Menurut WHO (world Health Organization), atas usia remaja adalah 12 sampai 24 tahun (Widiansyah, 2014).

Berdasarkan ilmu Psikologi perkembangan, remaja adalah suatu periode transisi dari masa awal anakanak hingga masa awal dewasa, yang dimasuki pada usia kira-kira 10 hingga 12 tahun dan berakhir pada usia 18 hingga 22 tahun (Sarwono, 1997). Monks berpendapat bahwa secara global masa remaja berlangsung antara 12-21 tahun, dengan pembagian 12-15 tahun merupakan masa remaja awal, 15-18 tahun merupakan masa remaja pertengahan, dan 18- 21 tahun merupakan masa remaja akhir (Monks, 2002). Sedangkan WHO menetapkan batas usia 10-20 tahun sebagai batasan usia remaja. Batasan usia tersebut didasarkan pada usia kesuburan (fertilitas) wanita yang berlaku juga untuk remaja pria, dan dibagi kurun usia tersebut menjadi dua bagian yaitu remaja awal (10-14 tahun) dan remaja akhir (15-20 tahun). Perserikatan Bangsa-Bangsa (PBB) sendiri menetapkan usia 15-24 tahun sebagai usia pemuda dalam rangka keputusan mereka untuk menetapkan tahun 1985 sebagai Tahun Pemuda Internasional (Kaparang, 2013).

\section{Pengertian ABK (Down Sindrome)}

Secara harfiah, syndrome diartikan sebagai suatu gejala atau tanda yang muncul. secara bersama-sama). Sementara kata down yang digunakan dalam hal ini adalah istilah yang diambil dari nama seorang dokter berkebangsaan Ingriss yaitu John
Langdon Down (Alwi, 2002) dalam (Rohmadheni, 2016).

Down syndrome atau trisomy 21 adalah kelainan yang menyebabkan penderita mengalami keterlambatan dalam pertumbuhannya (lambat bicara, duduk, dan jalan), kecacatan (bentuk kepala datar, hidung pesek, dII) dan kelemahan fisik (mudah lelah dan sakit) serta memiliki IQ yang relative rendah dibandingkan dengan orang normal pada umumnya (25-70). Kelainan ini diakibatkan kromosom 21 berjumlah 3 (pada orang normal 2) (NDSS, 2012) dalam (Mulia \& Kristi, 2012).

Down Syndrome adalah suatu kondisi keterbelakangan perkembangan fisik dan mental anak yang diakibatkan adanya abnormalitas perkembangan kromosom. Kromosom ini terbentuk akibat kegagalan sepasang kromosom untuk saling memisahkan diri saat terjadi pembelahan. Kromosom merupakan serat-serat khusus yang terdapat didalam setiap sel didalam badan manusia dimana terdapat bahan-bagan genetik yang menentukan sifat-sifat seseorang. Selain itu down syndrome disebabkan oleh hasil daripada penyimpangan kromosom semasa konsepsi. Ciri utama yang tampak pada kelainan ini adalah dari segi struktur muka dan satu atau ketidakmampuan fisik dan juga waktu hidup yang singkat (Semiun, 2006).

Menurut Mangunsong dkk (2009) Down Syndrome adalah mereka yang mempunyai kelainan badaniah yang sama dan penampilan wajah yang mirip dengan lainnya. Wajah mereka lebih rata daria anak-anak normal dan mata mereka sipit seperti anak mongol. Itu sebabnya muncul istilah anak mongol yang merupakan nama lain anak down syndrome. Menurut Mangunsong (2009) 
Lili Fadlilatin Azizah, Mas'odi

perkembangan perkembangan fisik maupun mental anak-anak Down Syndrome pada umumnya sangat lambat. Mereka terlambat duduk, berjalan dan melakukan hal-hal lain dibandingkan dengan teman-teman seusianya yang normal. Pada umumnya anak-anak down syndrome ini sering tertawa dan cepat melekat pada seseorang serta ramah tamah. Mereka tidak mengenal seksualits sehingga tidak mengenal masa pubertas. Mereka tidak dihinggapi perasaan-perasaan yang bertentangan dan tidak mengalami perwujudan perasaan yang menuju kedewasaan.

Kesimpulan yang diperoleh dari berbagai definisi di atas adalah down syndrome merupakan suatu kondisi keterbelakangan mental dan fisik yang disebabkan oleh kelainan kromosom. Anak yang mengalami down syndrome, biasanya memiliki IQ di bawah 50 .

\section{Ciri-ciri Anak Down Syndrome}

Anak Down Sindrome memiliki ciriciri fisik yang khas sehingga mereka mudah dikenali. Mangunson (2009) mengatakan ciri-ciri yang langsung terlihat ketika bayi down syndrome lahir adalah telinga yang kecil, tengkorak kepala pendek, kepala bagian belakang yang rata, leher yang pendek dengan lipatan-lipatan yang banyak, bentuk tubuh yang pendek dan lidah yang kuat. Pada garis telapak tangannya juga ada perbedaan. Pada anak normal, garis lengkung horisontal ada dua buah, sedangkan pada anak down syndrome hanya satu. Jari kelingking kelihata lebih pendek dan melengkung, belahan antara jempol kaki dan jari kedua lebih dalam, mata miring karena bagian luar mata agak tertarik mke atas dibandingkan dengan bagian dalam. Wajah yang rata, terdapat lipatan pada mata, rambut yang kaku dan sendi-sendi yang menutup satu dengan lainnya. Biasanya dan pada umumnya anak-anak down syndrome memang luwes dan lemah sekali. Tubuh anak dapat dilipat dan dilengkungkan dengan mudah, padahal anak-anak yang normal tidak dapat melakukan hal ini.

Davinson dkk (2006) mengatakan orang-orang yang mengalami down syndrome mengalami retardasi mental sedang hingga parah serta beberapa tanda fisik yang khas, seperti postur tubuh yang pendek dan gemuk, mata yang berbentuk ovel dan condong ke atas, lipatan kelopak mata bagian atas yang memanjang melewati sudut bagian dalam mata, rambut lurus yang tipis dan halus, hidung yang lebar dan datar, telinga berbentuk persegi, lidah yang besar dan berkerut yang menjulur keluar karena mulut yang kecil dengan langit-langit rendah dan tangan yang pendek serta lebar dengan jari-jari yang pendek.

Anak-anak dengan down syndrome menderita berbagai defisit dalam belajar dan perkembangan. Mereka cenderung tidak terkoordinasi dan kurang memiliki tekanan otot yang cukup sehingga sulit bagi mereka untuk melakukan tugas-tugas fisik dan terlibat dalam aktivitas bermain seperti anakanak lain. Anakanak ini mengalami defisit memori, khususnya untuk informasi yang ditampilkan secara verbal, sehingga sulit untuk belajar di sekolah. Mereka juga mengalami kesulitan mengikuti instruksi dari guru dan mengekspresikan pemikiran atau kebutuhan mereka dengan jelas secara verbal. Disamping kesulitan-kesulitan tersebut, sebagian besar dapat belajar membaca, menulis, dan mengerjakan tugastugas aritmatika sederhana bila mereka menerima pendidikan yang 
tepat dan dukungan yang baik (Nevid, dkk., 2003) dalam (Rina, 2016).

Hampir semua kemampuan kognitif anak cacat mental mengalami kelainan seperti lambat belajar, kemampuan mengatasi masalah, kurang dapat mengadakan hubungan sebab akibat, sehingga penampilan sangat berbeda dengan anak lainnya. Anak cacat mental ditandai dengan lemahnya kontrol motorik, kurang kemampuannya untuk mengadakan koordinasi, tetapi dipihak lain dia masih bisa dilatih untuk mencapai kemampuan sampai ke titik normal. Tanda-tanda lainnya seperti membaca buku ke dekat mata, mulut selalu terbuka untuk memahami sesuatu pengertian memerlukan waktu yang lama, mempunyai kesulitan sensoris, mengalami hambatan berbicara dan perkembangan verbalnya (Marta, 2017).

Mengenai prilaku pada anak-anak down syndrome banyak pendapat yang menjelaskan tentang perilaku. Beberapa diantaranya mengatakan bahwa anak-anak down syndrome adalah anak-anak yang tenang dan mudah diatur. Pendapat lain mengatakan bahwa mereka merupakan anak-anak yang keras kepala dan sulit dikontrol. Anak down syndrome dalam perkembangannya berbeda dengan anak normal. Anak down syndrome mempunyai keterlambatan dan keterbatasan dalam semua area perkembangan sehingga mereka mengalami kesulitan untuk merawat diri sendiri dan cenderung memiliki ketergantungan dengan lingkungan terutama pada orang tua dan saudarasaudaranya (Rampi, 2017).

\section{Jenis-jenis Down Syndrome}

Menurut Hidayat,.dkk (2018) Down Syndrome terbagi atas tiga tipe yaitu trisomi 21 reguler, translokasi dan mosaik, yaitu:

\section{a. Trisomi 21}

Yang pertama dan paling umum dijumpai (95\%) adalah trisomi 21 yang diakibatkan oleh ketidakberesan kromosom pada pasangan orang tuanya yang menurunkan jumlah kromosom menjadi 47 (23 pasang + 1) sehingga anak yang dilahirkan kelak akan mempunyai kelebihan satu kromosom oleh jajaran pasangan selnya pada nomor 21 , sehingga dijuluki trisomi 21.

\section{b. Mosaicims}

Mosaicims merupakan salah satu tipe kelainan down syndrome yang jarang sekali ditemui, dimana kelainan ini muncul disebabkan oleh adanya kesalahan saat terjadinya pembelahan sel di awal mitosis. Hal ini disebabkan oleh kemunculan kromosom lain yang berbeda pada saat kehidupan berdampingan dalam individu sel, yang diluar aturan semestinya (Robinson \& Robinson, dalam Delphie 1996).

\section{c. Translocation}

Jenis ini ialah jenis yang paling jarang, hanya melibatkan $2 \%$ dari pada semua individu-individu yang mempunyai down syndrome hanya dapat diturunkan oleh ibu atau bapak, lebih kurang satu dari pada tiga kejadian ini seorang dari pada ibu, bapak pembawa yang seimbang. Ini bermakna walaupun mereka adalah pembawa kromosom yang tidak sempurna, keseimbangannya menyebabkan ibu atau bapak itu sendiri tidak terlibat. Dalam keadaan "Translocation" Down Syndrome sebagian dari kromosom 21 terpecah dan bagian yang ketinggalan pula terlekat kepada pasangan kromosom 
Lili Fadlilatin Azizah, Mas'odi

yang lain dan kerap kali terjadi pada pasangan kromosom 14. sepanjang yang diketahui keadaan individuindividu yang mempunyai translocation

\section{Faktor-faktor Penyebab Penyebab Biologis}

Davison dkk (2006) mengatakan manusia normal memiliki 46 kromosom, sejumlah 23 diturunkan oleh ayah dan 23 lainnya diturunkan oleh ibu. Para individu yang mengalami down sindrome hampir selalu memiliki 47 kromosom bukan 46 . Ketika terjadi pematangan telur, dua kromosom pada pasangan kromosom 21 , yaitu kromosom terkecil, gagal membelah diri. Jika telur bertemu dengan sperma, akan terdapat 3 kromosom 21 yang diberi istilah trisomi 21.

Down syndrome terjadi karena kelainan susunan kromosom ke-21, dari 23 kromosom manusia. Pada manusia normal, 23 kromosom tersebut berpasangpasangan hingga jumlahnya menjadi 46 . Pada penderita down syndrome, kromosom nomor 21 tersebut berjumlah tiga (trisomi), sehingga totalnya menjadi 47 kromosom. Jumlah yang berlebihan tersebut mengakibatkan kegoncangan pada sistem metabolisme sel, yang akhirnya memunculkan down syndrome. Hingga saat ini, diketahui adanya hubungan antara usia sang ibu ketika mengandung dengan kondisi bayi. Yaitu semakin tua usia ibu, maka semakin tinggi pula risiko melahirkan anak dengan down syndrome (Monks, dkk, 2008).

Mangunsong (2009) mengungkapkan hal yang senada yaitu bahwa penyebab kelainannya berawal dari terbentuknya manusia. Setiap manusia terbentuk dari satu sel. Satu sel ini terjadi akibat pertemuan sperma (mani) dan sebuah sel telur. Tubuh kita terdiri dari sel-sel dan sel-sel ini mengandung kromosom-kromosom dan pada setiap sel terdapat 46 kromosom.
Kromosom tadi bukan saja menentukan penampilan diri kita tetapi juga menentukan ciri-ciri dan sifat manusia. Kromosom tidak saja menentukan bagaimana bentuk wajah kita, tetapi juga karakter, sifat dan bakat karena dalam kromosom ini terdapat unsurunsur keturunan. Separuh dari unsur-unsur keturunan berasal dari ibu dan separuhnya lagi dari ayah. Jadi dalam setiap sel ada 23 kromosom dari ibu dan 23 dari ayah. Seorang anak yang menderita down syndrome tidak mempunyai 46 kromosom melainkan 47. Dalam setiap sel mereka mempunyai kelebihan satu kromosom. Kelebihan satu kromosom ini selalu terdapat pada saudara kembar kromosomnomor 21. Itu sebabnya anak yang mengidap kelainan down syndrome memiliki tiga kromosom 21, bukan dua.

Down syndrome atau trisomy 21 adalah kelainan yang menyebabkan penderita mengalami keterlambatan dalam pertumbuhannya (lambat bicara, duduk, dan jalan), kecacatan (bentuk kepala datar, hidung pesek, dII) dan kelemahan fisik (mudah lelah dan sakit) serta memiliki IQ yang relative rendah dibandingkan dengan orang normal pada umumnya (25-70). Kelainan ini diakibatkan kromosom 21 berjumlah 3 (pada orang normal 2) (NDSS, 2012) dalam (Mulia \& Kristi, 2012). IQ anak down syndrome biasanya dibawah 50 , sifatsifat atau ciri-ciri fisiknya adalah berbeda, ciri-ciri jasmaniahnya sangat mencolok, salah satunya yang paling sering diamati adalah matanya yang serong ke atas. Penderita down syndrome biasanya mempunyai tubuh pendek dan puntung, lengan atau kaki kadang-kadang bengkok, kepala lebar, wajah membulat, mulut selalu terbuka, ujung lidah besar, hidung lebar dan datar, kedua lubang hidung terpisah lebar, jarak lebar antar kedua mata.

Dari beberapa karakteristik yang ada, dan paparan dari guru, orangtua setelah melalui proses observasi yang kemudian 
dilengkapi dengan pemeriksaan dari psikolog, dapat dipastikan bahwa subjek adalah penderita down syndrome dengan ciri-ciri tubuh pendek, bentuk wajah membulat, bentuk hidung mendatar dan lebar dan pandangan mata memicing. Sedangkan bentuk tangannnya lebar dan terlihat tumpul, bagi anak yang normal tubuh yang pendek dan kecil biasanya akan membentuk tangan yang yang pendek dan sesuai dengan bentuk tubuh, tapi lain halnya dengan subjek yang mempunyai tagan lebar besar menumpul. Beberapa ciri lainnya yang dapat menunjukkan bahwa subjek yang menderita down syndrome adalah mental dan sikap subjek yang seperti anak kecil. Kemampauan intelektual subjek setelah melalui pemeriksaan psikologis pada IQ, maka didapatkan Subjek hanya mempunyai IQ dibawah 50, karena ketidak mampuannya dalam menangkap materi yang telah diajarkan oleh guru. Sedangkan untuk jenisnya, dapat diperkirakan jenis down sindrome yang diderita oleh subjek adalah down sindrome dengan jenis Trisomi 21 yaitu jenis yang paling umum dijumpai (95\%) adalah trisomi 21 yang diakibatkan oleh ketidakberesan kromosom pada pasangan orang tuanya yang menurunkan jumlah kromosom menjadi 47 (23 pasang +1 ) sehingga anak yang dilahirkan akan mempunyai kelebihan satu kromosom oleh jajaran pasangan selnya pada nomor 21 , dijuluki trisomi 21 karena menurut ibu subjek kelainan atau sisi abnormaliatas ini tidak diturunkan secara genetik dan menurutnya pendahulupendahulunya baik dari ibu maupun dari pihak ayah tidak ada yang terkena down sindrome, melainkan hanya subjek sendiri.

\section{Pembahasan}

Untuk membantu Subjek dalam mengembangkan kemandiriannya dan optimalisasi motorik halusnya, maka peneliti ingin memberikan beberapa bentuk intervensi. Intervensi ini akan diberikan langsung pada subjek dan orang terdekat subjek yaitu ibu dan guru kelasnya. Dengan beberapa bentuk penanganan ini diharapkan menjadi bekal untuk kehidupan subjek saat ini dan selanjutnya. Oleh karena itu, tujuan utama dari intervensi ini adalah :

1. Membantu subjek ke arah belajar berperilaku self-help dengan mengembangkan aspek kemandiriannya.

2. Mengembangkan kemampuan komunikasi subjek, dengan cara membantu subjek untuk dapat mengungkapkan apa yang diinginkan.

\section{Membantu subjek dalam} mengembangkan motorik halusnya.

Pada proses penanganan pada subjek ini, peneliti memberikan beberapa bentuk intervensi untuk mengembangkan aspekaspek yang masih belum dicapai oleh subjek, yaitu aspek kemandirian dengan melalui pembinaan self-help pada subjek, kemampuan berkomunikasi yang masih belum berkembang secara optimal pada subjek dan aspek motorik halus untuk menunjang aspek kemandiriannya.

Seperti yang sudah dijelaskan sebelumnya bahwa subjek sampai saat ini masih belum mampu untuk melakukan selfhelp nya dengan baik, dengan keterbatasan yang dimilikinya. Hal itu seperti yang diungkapkan oleh Somantri (2007) perkembangan dorongan (drive) dan emosi berkaitan dengan kondisi down syndrome anak. Anak down syndrome tidak dapat menunjukkan dorongan pemeliharaan dirinya sendiri. Mereka tidak bisa menunjukkan rasa lapar atau haus dan tidak dapat menghindari bahaya.

Maka dari itu, untuk mengembangkan self-help pada subjek, peneliti melakukan pembinaan mengenai self-help pada subjek dengan menggunakan video kemandirian. Video kemandirian ini adalah video yang menunjukkan tentang 
Lili Fadlilatin Azizah, Mas'odi

kemudahan seorang anak untuk dapat melakukan self-help, tentunya hal tersebut juga tetap melalui penjelasan yang mendetail dari peneliti, dan diberikan secara berulang-ulang agar dapat dipahami dengan baik. Peneliti memberikan bentuk intervensi ini dikarenakan anak down syndrome akan lebih mudah belajar dengan cara meniru. Seperti yang diungkapkan oleh Namira (2012), anak-anak down syndrome lebih mudah belajar dari pengalaman nyata. Karena itu, melatih anak down syndrome dengan membuat mereka belajar dari apa yang mereka lakukan akan lebih efektif daripada memberikan penjelasan lisan. Pada akhirnya, dengan pemberian materi yang disesuaikan dengan tingkat kemampuan anak down syndrome dan penggunaan tekhnik atau cara tertentu, maka diharapkan adanya perubahan perilaku pada anak.

Hal senada diungkapkan oleh Soemantri (2007) bahwa ketepatan (keakuratan) respon anak down syndrome kurang daripada respon anak normal. Ytetapi bila tugas yang diberikan bersifat diskriminasi visual, ternyata anak down syndrome hampir sama dengan yang diperoleh anak normal. Oleh karena beberapa teori tersebut peneliti melakukan intervensi pada subjek dengan cara pemberian video selfhelp, pemberian dongeng untuk mengembangkan kemampuan komunikasinya, dan beberapa bentuk penanganan untuk mengoptimalkan perkembangan motorik halusnya. Optimalisasi motorik halus untuk menunjang perkembangan self-help pada subjek.

Untuk mencapai tujuan-tujuan dari penanganan, maka peneliti melakukan proses-proses penanganan yang akan dijelaskan dibawah ini:
Memberikan Tontonan Video Kemandirian. Tujuan dari penanganan ini adalah untuk mengembangkan sikap mandiri pada diri Subjek. Pada proses penanganan ini peneliti memberikan video dengan tema self-help. Hal ini dimaksudkan agar subjek dapat mengembangkan sikap self-help nya dengan meniru sikap-sikap yang dicontohkan oleh tokoh dalam video tersebut. Pada awalnya, subjek tidak tertarik untuk melihat video yang diputar oleh peneliti, namun setelah peneliti mengajak guru dan beberapa orang temannya untuk menonton video tersebut, subjekpun ikut serta menonton. Sambil menonton peneliti menjelaskan alur cerita pada subjek dengan gaya bahasa seperti tokoh dalam video. Peneliti mengajak subjek untuk menonton video ini sebanyak 4 kali, yaitu pada hari pertama peneliti melakukan program penanganan ini, kemudian 3 hari setelahnya. Subjek sangat menyukai video ini, beberapa kali tanpa tersadar subjek mengikuti gaya yang diperankan oleh tokoh.

Dongeng untuk mengembangkan aspek komunikasi subjek. Tujuan dari penanganan ini adalah mengembangkan sikap subjek untuk senantiasa mampu mengungkapkan apa yang dialaminya. Pada proses penanganan ini peneliti membacakan cerita dengan gaya yang dapat dipahami oleh subjek. Cerita yang dibacakan oleh peneliti adalah cerita tentang kebersihan lingkungan. Dalam membacakan cerita ini peneliti bertindak seolah-olah peneliti memerankan tokoh dalam cerita tersebut. Subjek sangat antusias dalam mengikuti proses penanganan ini. Peneliti memberikan penanganan ini sebanyak 2 kali. Dengan proses ini subjek diharapkan mampu mengembangkan kemampuan berkomunikasi pada subjek.

Pengembangan motorik halus. Tujuan dari penanganan ini adalah untuk mengembangkan motorik halus. Pada proses penanganan ini peneliti 
memberikan bebrapa rangkaian metode untuk mengembangkan motorik halus Subjek.

Membuat model origami berbentuk amplop dan perahu. Pada proses ini peneliti dan guru mengajak subjek untuk membuat origami yang berbentuk amplop. Sebelumnya peneliti memnuat terlebih dahulu untuk dijadikan contoh, kemudian setelah melihat contoh yang diberikan peneliti subjek diminta untuk membuat hal yang serupa. Pembuatan origami ini berlangsung selama 2 kali ( 2 hari).

Membuat bentuk dengan plastisin. Pada proses ini, peneliti memberikan intervensi pada subjek dengan mengajak subjek untuk membuat beberapa bentuk dengan menggunakan plastisin. Bentuk yang dibuat adalah beberapa macam kue. Proses pemberian intervensi ini hampir sama dengan pembuatan origami. Proses ini hanya dilakukan 1 kali selama peneliti praktikum di sekolah.

Merobek dan menempel. Pada proses ini peneliti mengajak subjek untuk merobek beberapa kertas berwarna dan kemudian meminta subjek untuk menempelkan pada objek tertentu yang sudah disediakan oleh peneliti . Proses ini hanya dilakukan 1 kali saja, untuk menjadi contoh pada guru dalam melanjutkan intervensi yang diberikan peneliti .

Menggunting dan menempel. Pada proses ini subjek diminta untuk menggunting gambar yang sudah disediakan oleh peneliti untuk kemudian ditempelkan pada gambar yang sudah disediakan.

Setelah melakukan penanganan pada subjek dengan menggunakan beberapa proses penanganan yang diberikan peneliti pada subjek, yaitu dengan berusaha mengembangkan aspek kemandiriannya dengan mempertontonkan video yang kemadirian yang sudah disiapkan peneliti, kepekaan terhadap lingkungan dengan mendongeng tema kepekaan lingkungan dengan gaya khas peneliti serta mengembangkan motorik halus subjek dengan beberapa proses intervensi di dalamnya. Proses penanganan ini berlangsung selama 10 hari, yaitu 4 hari dengan menonton video, 2 hari mendongeng, dan 4 hari setelahnya dengan proses-proses pengembangan motorik halus.

Setelah melakukan penanganan pada subjek, maka didapatkan hasil yang memuaskan. Menurut penuturan ibu subjek, subjek di rumah sudah tak mau dimandikan lagi, saat tiba waktu mandi subjek akan meminta peralatan mandi dan kemudian mandi sendiri, dan setelah mandi, subjek akan menggunakan pakaiannya sendiri, namun pakaian masih perlu disiapkan sebelumnya. Saat peneliti menanyakan pada ibu subjek tentang bersih tidaknya saat subjek mandi sendiri, ibu subjek mengatakan bahwa subjek mandi dengan bersih seusai dengan yang diajarkan ibunya saat memandikannya. Begitu halnya dengan kepekaan sosialnya, saat ini subjek sudah mulai peka terhadap kebersihan di lingkungan sekitarnya, terbukti saat melihat sampah, subjek akan membuangnya di tempat sampah.

\section{Kesimpulan}

Subjek adalah seorang anak perempuan. Dia adalah seorang siswa kelas 2 di Sekolah Dasar Luar Biasa di Saronggi Sumenep Madura. Dia adalah anak terakhir dari empat bersaudara, ketiga saudaranya adalah seorang laki-laki. Subjek terlahir normal seperti anak yang lain, ibu subjek pun tidak mengalami gangguan apapun saat kehamilan. Tampilan fisik saat baru dilahirkan terlihat sama dengan anak yang lain, subjek dilahirkan di usia normal kandungan, namun subjek kesulitan dalam berkomunikasi, subjek tidak dapat mengatakan kalimat sempurna, 
Lili Fadlilatin Azizah, Mas'odi

bahkan kata-kata yang diucapkan sangat sulit dipahami. Kondisi fisik subjek di usianya yang sudah menginjak 14 tahun ini tidak ada perubahan, bentuk tubuhnya pendek seperti anak yang berumur 7 tahun, sifatnyapun seperti anak kecil. Diagnosa pertama yang diberikan peneliti terhadap subjek adalah bahwa subjek mengalami down sindrome.

Dengan kondisinya yang demikian berbeda dengan anak-anak yang lain subjek tetap dapat mudah berinteraksi dengan sesamanya, bahkan subjek tidak takut dengan orang baru, subjek lebih ingin mendapat perhatian saat ada orang yang baru, hal ini ditunjukkan dengan sikap ingin diperhatikan dengan cara melakukan halhal yang tidak biasanya dilakukan oleh subjek, misalnya memeluk orang yang baru dikenalnya. Saat proses pembelajaran di kelas subjek hanya menangkap kata-kata yang diucapkan oleh guru, subjek masih sangat kesulitan dalam menulis huruf dan belum bisa membaca, kemampuan menulisnya pun sangat lambat, dia hanya dapat menulis huruf-huruf yang telah dicontohkan di depannya.

Setelah melakukan penanganan pada subjek, maka didapatkan hasil yang memuaskan. Menurut penuturan ibu subjek, subjek di rumah sudah tak mau dimandikan lagi, saat tiba waktu mandi subjek akan meminta peralatan mandi dan kemudian mandi sendiri, dan setelah mandi, subjek akan menggunakan pakaiannya sendiri, namun pakaian masih perlu disiapkan sebelumnya.
Untuk mengoptimalisasikan apa yang sudah dilakukan oleh peneliti setelah pemberian intervensi pada subjek, maka berikut ini saran yang dapat peneliti berikan kepada pihak-pihak yang terkait dengan subjek.

Pada orangtua. Down syndrome merupakan bentuk keterbelakangan mental yang disebabkan karena adanya abnormalitas kromosom, sehingga berdampak pada kualitas hidup individu. Meskipun beberapa keterbatasan genetik fisik pada subjek tidak dapat diatasi, pendidikan dan perawatan yang tepat akan meningkatkan kualitas hidupnya. Subjek dapat dilatih dan dididik secara khusus, dengan cara memberikan keterampilan, mengajaknya berinteraksi satu sama lain, perawatan medis di tempat yang ditentukan dan beberapa pelatihan di lingkungan keluarga yang kondusif. Dan hal yang paling penting, adalah sikap memahami dan penerimaan tanpa syarat (unconditional positive regards) dari orangtua dan keluarga terdekat subjek, agar subjek juga dapat mengaktualisasikan dirinya dengan segala keterbatasan dan potensi dimilikinya.

Pada Guru Kelas. Guru kelas di sekolah hendaknya lebih memberikan perhatian khusus kepada siswa yang mempunyai kelainan seperti subjek ini, mempelajari sifat-sifat dan karakternya. Dengan demikian diharapkan Guru sekolah dapat membantu menangani permasalahan siswa-siswa yang mempunyai kelainan khusus seperti subjek ini. 


\section{DAFTAR PUSTAKA}

Davison, G.C., Neale, J.M., Kring, AM. (2006). Psikologi Abnormal (terjemahan). Jakarta: PT Raja grafindo Persada (Edisi kesembilan)

Hidayat, Yogi Nur. Dkk, . 2018. Penerapan Konsep Arsitektur Perilaku Pada Bangunan Pusat Rehabilitasi Down Syndrome Di Jakarta. Jurnal Arsitektur PURWARUPA Volume 2 No 2 September 2018: 43-56

Kaparang, Olivia M. 2013. Analisa Gaya Hidup Remaja Dalam Mengimitasi Budaya Pop Korea Melalui Televisi. Journal "Acta Diurna". Vol.II/No.2/2013.

Mangunsong, Frida. (2009). Psikologi Dan Pendidikan Anak Berkebutuhan Khusus. Jakarta: LPSP3 UI

Marta, Rusdial. 2017. Penanganan Kognitif Down Syndrome melalui Metode Puzzle pada Anak Usia Dini. Riau : Jurnal Obsesi Volume 1 Nomor 1 Tahun 2017 Halaman $32-41$.

Mulia, Amanda \& Eunike Kristi. 2012. Fasilitas Terapi Anak Down syndrome di Surabaya. Surabaya: JURNAL eDIMENSI ARSITEKTUR, No. 1 (2012) 1-6.

Rampi, Chrisly E. N. D. dkk,. 2017. Gambaran kebersihan gigi dan mulut pada anak penderita down syndrome di slb ypac manado. Jurnal KEDOKTERAN KLINIK (JKK), Volume 1 No 3 , April 2017

Rina, Amherstia Pasca. 2016. Meningkatkan Life Skill pada Anak Down Syndrome dengan Teknik Modelling. Surabaya : Fakultas Psikologi UNTAG Surabaya, Jurnal : Persona Vol. 5, No. 03, hal 215- 225.

Rohmadheny, Prima Suci. 2016. Case Study Of Down Syndrome Child. Madiun: IKIP PGRI Madiun, Jurnal CARE Edisi Khusus Temu IImiah (Vol. 03 No.3 Maret 2016).

Semiun, Yustinus. (2006). Kesehatan Mental 2. Yogyakarta: Kanisius (Anggota IKAPI)

Soemantri, Sutjihati. (2007). Psikologi Anak Luar Biasa. Bandung : PT. Refika Aditama.

Widiansyah, Muhammad. 2014. Faktor-Faktor Penyebab Perilaku Remaja Perokok Di Desa Sidorejo Kabupaten Penajam Paser Utara. eJournal Sosiologi, 2014, 2 (4): 1-12. 